\title{
Arsenic in Bangladesh Soils and Its Relationship with Water Soluble Soil Organic Carbon
}

\author{
Shurovi Zaman ${ }^{*}$, Anjuman Ara Rajonee ${ }^{2}$, Shah Muhammad Imamul Huq ${ }^{3}$ \\ ${ }^{1}$ Department of Environmental Science and Disaster Management, Noakhali Science and Technology University, Noakhali, \\ Bangladesh \\ ${ }^{2}$ Department of Soil and Environmental Sciences, University of Barisal, Barisal, Bangladesh \\ ${ }^{3}$ Vice Chancellor, University of Barisal, Barisal, Bangladesh \\ Email: *szaman_29@yahoo.com
}

How to cite this paper: Zaman, S., Rajonee, A.A. and Imamul Huq, S.M. (2017) Arsenic in Bangladesh Soils and Its Relationship with Water Soluble Soil Organic Carbon. Open Journal of Soil Science, 7, 77-85.

https://doi.org/10.4236/ojss.2017.74006

Received: March 7, 2017

Accepted: April 17, 2017

Published: April 20, 2017

Copyright $\odot 2017$ by authors and Scientific Research Publishing Inc. This work is licensed under the Creative Commons Attribution International License (CC BY 4.0).

http://creativecommons.org/licenses/by/4.0/

\begin{abstract}
An experiment was done to see the effect of water soluble organic carbon in soil on the release of arsenic (As). Fifty soil samples, rich in organic carbon were collected from five districts of Bangladesh namely Comilla, Jessore, Satkhira, Gopalganj and Bagerhat. Water soluble organic carbon (WSOC) of the analyzed samples ranged between 15 to $466 \mathrm{mg} / \mathrm{L}$ with an average of about $155 \mathrm{mg} / \mathrm{L}$ whereas the arsenic concentrations varies between 1.4 to $5.9 \mathrm{mg} / \mathrm{L}$ with an average of $4.2 \mathrm{mg} / \mathrm{L}$. The arsenic contents were much higher in soils where peat deposits are prominent (Gopalganj). There has been a log-log relationship between WSOC and soil, as for all the soils, the $\mathrm{R}^{2}$ ranging from 0.355 to 0.811 . Correlation between water soluble organic carbon and soil arsenic showed a positive and significant relation between the two parameters indicating the fact that organic or peat deposits contributes to the release of arsenic in Bangladesh environments.
\end{abstract}

\section{Keywords}

Arsenic Hot Spots, Contaminated Groundwater, Release of Arsenic,

Peat Deposits

\section{Introduction}

The widespread use of arsenic contaminated groundwater for irrigation has been reported to pose the risk of soil build-up of arsenic and its subsequent transfer to plants [1] [2] [3] [4]. Arsenic contamination of ground water is instrumental in creating not only health problems; it is also aggravating crop production systems in arsenic hot spots too in the country. The Bengal Delta Plain has become one of the most severely contaminated parts in the world [5]. In Bangladesh, 
groundwater is the primary source of drinking water for up to $90 \%$ of the total population [6]. In some areas of Bangladesh, groundwater arsenic concentrations reach $2 \mathrm{mg} \mathrm{L}^{-1}$ [7] [8], where the WHO provisional guideline value for drinking water is only $0.01 \mathrm{mg} \mathrm{L}^{-1}$. In tube-wells from 41 of the total 64 districts in Bangladesh, $51 \%$ of the samples were above $0.01 \mathrm{mg} \mathrm{L}^{-1}$ (WHO-permissible limit for drinking water), $35 \%$ were above $0.05 \mathrm{mg} \mathrm{L}^{-1}, 25 \%$ were above $0.10 \mathrm{mg}$ $\mathrm{L}^{-1}, 8.4 \%$ were above $0.3 \mathrm{mg} \mathrm{L}^{-1}$, and $0.1 \%$ were above $1.0 \mathrm{mg} \mathrm{L}^{-1}$ [8]. An estimated population of 25 million are exposed to arsenic concentrations of more than $0.05 \mathrm{mg} \mathrm{L}^{-1}$ (Bangladesh permissible limit), and the number would be approximately doubled if WHO limit of $0.01 \mathrm{mg} \mathrm{L}^{-1}$ were adopted [9]. In Bangladesh, irrigation is mostly dependent on groundwater. Background levels of ar-

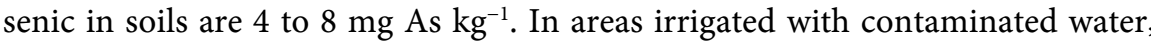

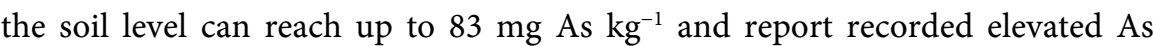

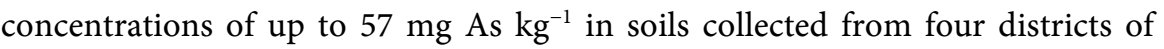
Bangladesh [10].

The biogeochemical cycle of naturally occurring arsenic in the terrestrial as well as aquatic environment has been extensively studied in recent years due to increased awareness of arsenic contamination and toxicity [11]. Under natural conditions, the highest concentration of arsenic are found in groundwater as a result of water-rock interactions and the greater tendency in aquifers for the physical and geochemical conditions seem to be favorable for arsenic mobilization and accumulation. It is opined that the distributions of organic matter, particularly peat deposits, in the aquifer sediment primarily control the arsenic release mechanism [12]. Water soluble organic carbon is considered to have an effect on origin of groundwater arsenic. The aim of this research is to investigate the effect of water soluble organic carbon fractions on arsenic and to derive hypotheses for possible future trends.

\section{Materials and Methods}

Fifty sites in five districts of Bangladesh were selected for collecting the samples for the experiment. Fourteen soil samples were collected from Comilla district, five from Jessore district, eight from Satkhira, eighteen from Gopalganj and five from Bagerhat district.

The bulk of soil samples representing $0-15 \mathrm{~cm}$ depth from the surface were collected by random soil sampling method as suggested by the Soil Survey Staff of the [13]. The samples were collected with spade and put into polythene bags, tagged with rubber band and labeled.

Once the soil samples were transported to the laboratory, these were dried in the air for 4 days (at $40^{\circ} \mathrm{C}$ ) by spreading them in a thin layer on a clean piece of paper. Visible roots and debris were removed from the soil samples and discarded. For hastening the drying process, the soil samples were exposed to sunlight. After air-drying, a portion of larger and massive aggregates were broken down by gently crushing them using a wooden hammer. Ground samples were screened to pass through a $2 \mathrm{~mm}$ stainless still sieve. These soil samples were 
used for the determination of water soluble organic carbon content of soils. A portion of the soil samples ( $2 \mathrm{~mm}$ sieved) were further ground and screened to pass through a $0.5 \mathrm{~mm}$ sieve. These soils were used for arsenic determination of the soils.

The content of the water soluble carbon compound was determined by Tyurin method and by determination of the dichromatic oxidation rate of the water. A flask with 1 gram of soil with $25 \mathrm{~cm}^{3}$ of distilled water was shaken using a rotation for 15 minutes; then the suspension obtained was left for 24 hour. Next, it was shaken for 15 minutes again. The suspension was filtered using a dense filter, and, after the filtration, the volume was measured using a measuring cylinder. Aliquots $\left(10 \mathrm{~cm}^{3}\right)$ of the water extracts were taken for the analysis [14].

Arsenic in soil was extracted by digestion with aqua-regia. For determination of aqua-regia extractable arsenic, $2.5 \mathrm{gm}$ soil was digested in $20 \mathrm{ml}$ aqua-regia for approximately 3 - 4 hours using a sand bath as a heating source (app. $150^{\circ} \mathrm{C}$ ). The sample and acid were placed in $100 \mathrm{ml}$ Pyrex glass beaker. After dissolution, samples were diluted up to a volume of $100 \mathrm{ml}$, mixed and filtered prior to analysis [15].

The arsenic content of the soil samples were determined from the extract by Hydride Generation Atomic Absorption Spectrophotometry (HGAAS) with the help of $50 \% \mathrm{KI}$ and $10 \%$ Urea in acid medium. Standard solutions were prepared from sodium meta-arsenite. Standard solutions were prepared freshly from the dilution of $10.0 \mathrm{mg}$ As (III) $\mathrm{L}^{-1}$ stock solutions. Concentration of arsenic were determined using the solutions containing $10.0 \mathrm{ml}$ of sample (or standard), $10.0 \mathrm{ml}$ of concentrated $\mathrm{HCl}$ and $0.50 \mathrm{ml}$ of Urea reagent $(80 \% \mathrm{~W} / \mathrm{V})$ that were reduced by adding $0.50 \mathrm{ml} \mathrm{KI}$ reagent $(40 \% \mathrm{~W} / \mathrm{V}), 30$ to 60 minutes prior to analyses [16]. Standard concentration of 5, 10, 15, 20 and $30 \mu \mathrm{g}$ As (III) $\mathrm{L}^{-1}$ were used. The hybride was generated using $6 \mathrm{~N} \mathrm{HCl}$ and $1.2 \% \mathrm{NaBH}_{4}$ and $1 \% \mathrm{NaOH}$ in deionized water (Portman and Riley, 1964). After completion of all these preparations, sample reading was taken using Hydride Generation Atomic Absorption Spectrophotometry (HGAAS).

All extractions and analyses were done in triplicates. Correlations among various pairs were calculated to determine significant differences between the groups at $\mathrm{P}<0.05$. MINITAB (version 15) Packages and Microsoft Excel were used for the statistical and graphical evaluations.

\section{Results and Discussion}

\subsection{Water Soluble Organic Carbon}

The maximum and minimum values of water soluble organic carbon of the 50 soil samples are $466 \mathrm{mg} / \mathrm{L}$ and $15 \mathrm{mg} / \mathrm{L}$ respectively. The average value of water soluble organic carbon of 50 soil samples is $154.66 \mathrm{mg} / \mathrm{L}$ (standard deviation \pm 78.23). The water soluble organic carbon of the soil samples from different districts showed that those from Comilla district ranged from $15 \mathrm{mg} / \mathrm{L}$ to $191 \mathrm{mg} / \mathrm{L}$ and the average value is $117.5 \mathrm{mg} / \mathrm{L}$ (standard deviation \pm 53.19 ); those from Jessore district ranged from $46 \mathrm{mg} / \mathrm{L}$ to $173 \mathrm{mg} / \mathrm{L}$ and the average value is 138 
$\mathrm{mg} / \mathrm{L}$ (standard deviation \pm 54.49 ); those from Satkhira district ranged from 87 $\mathrm{mg} / \mathrm{L}$ to $392 \mathrm{mg} / \mathrm{L}$ with an average value of $168.75 \mathrm{mg} / \mathrm{L}$ (standard deviation \pm 106.09); those from Gopalganj district ranged from $78 \mathrm{mg} / \mathrm{L}$ to $466 \mathrm{mg} / \mathrm{L}$ and the average value is $174.22 \mathrm{mg} / \mathrm{L}$ (standard deviation \pm 89.17) while water soluble organic carbon of the soil samples of Bagerhat district ranged from $147 \mathrm{mg} / \mathrm{L}$ to $221 \mathrm{mg} / \mathrm{L}$ and the average value is $182.4 \mathrm{mg} / \mathrm{L}$ (standard deviation \pm 32.49 ) (Tables 1(a)-(e)).

\subsection{Arsenic (As)}

The maximum and minimum concentrations of arsenic in the 50 soil samples have been found to be $5.94 \mathrm{mg} / \mathrm{L}$ and $1.41 \mathrm{mg} / \mathrm{L}$ respectively. The average value of arsenic is $4.21 \mathrm{mg} / \mathrm{L}$ (standard deviation \pm 1.27 ). Arsenic of the soil samples from different districts showed that arsenic in the soil samples of Comilla district ranged from $1.84 \mathrm{mg} / \mathrm{L}$ to $5.94 \mathrm{mg} / \mathrm{L}$ with an average concentration of 4.28 $\mathrm{mg} / \mathrm{L}$ (standard deviation \pm 1.26 ); those from Jessore district ranged from 1.41 $\mathrm{mg} / \mathrm{L}$ to $3.92 \mathrm{mg} / \mathrm{L}$ and the average concentration is $2.75 \mathrm{mg} / \mathrm{L}$ (standard deviation \pm 1.08 ); those from Satkhira district ranged from $3.48 \mathrm{mg} / \mathrm{L}$ to $5.71 \mathrm{mg} / \mathrm{L}$ and the average concentration is $4.62 \mathrm{mg} / \mathrm{L}$ (standard deviation \pm 0.92 ); those from Gopalganj district ranged from $2.2 \mathrm{mg} / \mathrm{L}$ to $5.98 \mathrm{mg} / \mathrm{L}$ and the average concentration is $4.40 \mathrm{mg} / \mathrm{L}$ (standard deviation \pm 1.39 ) while arsenic concentration of the soil samples of Bagerhat district ranged from $3.26 \mathrm{mg} / \mathrm{L}$ to $5.36 \mathrm{mg} / \mathrm{L}$ and the average concentration is $4.11 \mathrm{mg} / \mathrm{L}$ (standard deviation \pm 0.80 ) (Tables $1(\mathrm{a})-(\mathrm{e}))$.

\subsection{Relation between Water Soluble Organic Carbon and Arsenic}

Correlation between soluble organic carbon and the corresponding arsenic in

Table 1. (a) Concentration of Arsenic and Water soluble organic carbon of the soil samples of Comilla district; (b) Concentration of Arsenic and Water soluble organic carbon of the soil samples of Jessore district; (c) Concentration of Arsenic and Water soluble organic carbon of the soil samples of Satkhira district; (d) Concentration of Arsenic and Water soluble organic carbon of the soil samples of Gopalganj district; (e) Concentration of Arsenic and Water soluble organic carbon of the soil samples of Bagerhat district.

(a)

\begin{tabular}{lccccccc}
\hline Sample Name & $\mathrm{S}(\mathrm{C} 1)$ & $\mathrm{S}(\mathrm{C} 2)$ & $\mathrm{S}(\mathrm{C} 3)$ & $\mathrm{S}(\mathrm{C} 4)$ & $\mathrm{S}(\mathrm{C} 5)$ & $\mathrm{S}(\mathrm{C} 6)$ & $\mathrm{S}(\mathrm{C} 7)$ \\
\hline Arsenic $(\mathrm{mg} / \mathrm{L})$ & 4.24 & 3.35 & 4.75 & 5.13 & 3.22 & 4.93 & 4.55 \\
WSOC $(\mathrm{mg} / \mathrm{L})$ & 93 & 135 & 90 & 173 & 90 & 69 & 122 \\
Sample Name & $\mathrm{S}(\mathrm{C} 8)$ & $\mathrm{S}(\mathrm{C} 9)$ & $\mathrm{S}(\mathrm{C} 10)$ & $\mathrm{S}(\mathrm{C} 11)$ & $\mathrm{S}(\mathrm{C} 12)$ & $\mathrm{S}(\mathrm{C} 13)$ & $\mathrm{S}(\mathrm{C} 14)$ \\
Arsenic $(\mathrm{mg} / \mathrm{L})$ & 4.80 & 5.94 & 4.63 & 4.91 & 1.84 & 1.93 & 5.75 \\
WSOC $(\mathrm{mg} / \mathrm{L})$ & 107 & 163 & 153 & 191 & 15 & 53 & 191 \\
\hline
\end{tabular}

(b)

\begin{tabular}{cccccc}
\hline Sample Name & $\mathrm{S}(\mathrm{J} 1)$ & $\mathrm{S}(\mathrm{J} 2)$ & $\mathrm{S}(\mathrm{J} 3)$ & $\mathrm{S}(\mathrm{J} 4)$ & $\mathrm{S}(\mathrm{J5})$ \\
\hline Arsenic $(\mathrm{mg} / \mathrm{L})$ & 3.1 & 1.84 & 3.5 & 1.41 & 3.92 \\
WSOC (mg/L) & 173 & 130 & 168 & 46 & 173 \\
\hline
\end{tabular}


(c)

\begin{tabular}{ccccccccc}
\hline Sample Name & S(S1) & S(S2) & S(S3) & S(S4) & S(S5) & S(S6) & S(S7) & S(S8) \\
\hline Arsenic $(\mathrm{mg} / \mathrm{L})$ & 4.94 & 3.56 & 5.3 & 4.42 & 5.7 & 3.89 & 3.48 & 5.71 \\
WSOC $(\mathrm{mg} / \mathrm{L})$ & 95 & 87 & 392 & 90 & 208 & 107 & 137 & 234 \\
\hline
\end{tabular}

(d)

\begin{tabular}{ccccccc}
\hline Sample Name & $\mathrm{S}(\mathrm{G} 1)$ & $\mathrm{S}(\mathrm{G} 2)$ & $\mathrm{S}(\mathrm{G} 3)$ & $\mathrm{S}(\mathrm{G} 4)$ & $\mathrm{S}(\mathrm{G} 5)$ & $\mathrm{S}(\mathrm{G} 6)$ \\
\hline Arsenic $(\mathrm{mg} / \mathrm{L})$ & 5.81 & 4.80 & 2.20 & 3.81 & 2.70 & 5.89 \\
WSOC $(\mathrm{mg} / \mathrm{L})$ & 176 & 155 & 78 & 115 & 98 & 262 \\
\hline Sample Name & $\mathrm{S}(\mathrm{G} 7)$ & $\mathrm{S}(\mathrm{G} 8)$ & $\mathrm{S}(\mathrm{G} 9)$ & $\mathrm{S}(\mathrm{G} 10)$ & $\mathrm{S}(\mathrm{G} 11)$ & $\mathrm{S}(\mathrm{G} 12)$ \\
\hline Arsenic $(\mathrm{mg} / \mathrm{L})$ & 2.51 & 3.62 & 5.20 & 3.55 & 3.07 & 5.27 \\
WSOC $(\mathrm{mg} / \mathrm{L})$ & 199 & 131 & 160 & 137 & 115 & 233 \\
\hline Sample Name & $\mathrm{S}(\mathrm{G} 13)$ & $\mathrm{S}(\mathrm{G} 14)$ & $\mathrm{S}(\mathrm{G} 15)$ & $\mathrm{S}(\mathrm{G} 16)$ & $\mathrm{S}(\mathrm{G} 17)$ & $\mathrm{S}(\mathrm{G} 18)$ \\
\hline Arsenic $(\mathrm{mg} / \mathrm{L})$ & 5.12 & 5.70 & 5.70 & 2.42 & 5.77 & 5.98 \\
WSOC $(\mathrm{mg} / \mathrm{L})$ & 168 & 204 & 128 & 90 & 466 & 221 \\
\hline
\end{tabular}

(e)

\begin{tabular}{rccccc}
\hline Sample Name & $\mathrm{S}(\mathrm{B} 1)$ & $\mathrm{S}(\mathrm{B} 2)$ & $\mathrm{S}(\mathrm{B} 3)$ & $\mathrm{S}(\mathrm{B} 4)$ & $\mathrm{S}(\mathrm{B} 5)$ \\
\hline Arsenic $(\mathrm{mg} / \mathrm{L})$ & 4.31 & 3.94 & 3.26 & 3.67 & 5.36 \\
WSOC $(\mathrm{mg} / \mathrm{L})$ & 198 & 196 & 147 & 150 & 221 \\
\hline
\end{tabular}

soils of five districts was calculated to observe any relationship between the two parameters. There exists a significant positive relationship between the two, signifying the fact that arsenic release in Bangladesh environment is related to the organic carbon contents of soil (Figure 1). The trend line, $y=0.009 x+2.755$ and $\mathrm{R}^{2}$ being 0.334 further confirm this $(\mathrm{P}=0.000$ and Pearson correlation of water soluble organic carbon and arsenic $=0.578$ ).

The arsenic in Comilla, Jessore, Satkhira, Gopalganj and Bagerhat districts were also found to be directly correlated with soluble organic carbon. The $\mathrm{P}$ and the Pearson correlation values are 0.002, 0.052, 0.099, 0.009, 0.037 and 0.754, $0.875,0.623,0.596,0.901$ respectively. The results are presented in Figures 2-6; Table 1(e). The trend line being $\mathrm{y}=0.017 \mathrm{x}+2.186, \mathrm{y}=0.017 \mathrm{x}+0.358, \mathrm{y}=$ $0.005 x+3.713, y=0.009 x+2.78, y=0.022 x+0.062$ with $R^{2}$ of $0.568,0.766$, $0.388,0.355,0.811$ for Comilla, Jessore, Satkhira, Gopalganj and Bagerhat respectively.

In soils of Comilla district for $\mathrm{S}(\mathrm{C} 12)$ the arsenic concentration was found to be $1.84 \mathrm{mg} / \mathrm{L}$ and the corresponding WSOC was $15 \mathrm{mg} / \mathrm{L}$ while in S(C9), the arsenic concentration was $5.94 \mathrm{mg} / \mathrm{L}$ where the WSOC was $163 \mathrm{mg} / \mathrm{L}$. In soils of Jessore district $S(J 4)$, arsenic concentration was found to be $1.41 \mathrm{mg} / \mathrm{L}$ and the corresponding WSOC was $46 \mathrm{mg} / \mathrm{L}$ while in soil S(J5), arsenic concentration was $3.92 \mathrm{mg} / \mathrm{L}$ where the WSOC was $173 \mathrm{mg} / \mathrm{L}$. In soils of Satkhira district S(S2), arsenic concentration was found to be $3.56 \mathrm{mg} / \mathrm{L}$ and the corresponding WSOC was $87 \mathrm{mg} / \mathrm{L}$ while in soil $\mathrm{S}(\mathrm{S} 8)$, arsenic concentration was $5.71 \mathrm{mg} / \mathrm{L}$ where the 
WSOC was $234 \mathrm{mg} / \mathrm{L}$. In soils of Gopalganj S(G3), arsenic concentration was found to be $2.2 \mathrm{mg} / \mathrm{L}$ and the corresponding WSOC was $78 \mathrm{mg} / \mathrm{L}$ while in soil $\mathrm{S}(\mathrm{G} 18)$, arsenic concentration was $5.98 \mathrm{mg} / \mathrm{L}$ where the WSOC was $221 \mathrm{mg} / \mathrm{L}$ and in soils of Bagerhat, S(B3), arsenic concentration was $3.26 \mathrm{mg} / \mathrm{L}$ where the WSOC was $147 \mathrm{mg} / \mathrm{L}$ while in soil S(B5), arsenic concentration was $5.36 \mathrm{mg} / \mathrm{L}$ where the WSOC was $221 \mathrm{mg} / \mathrm{L}$.

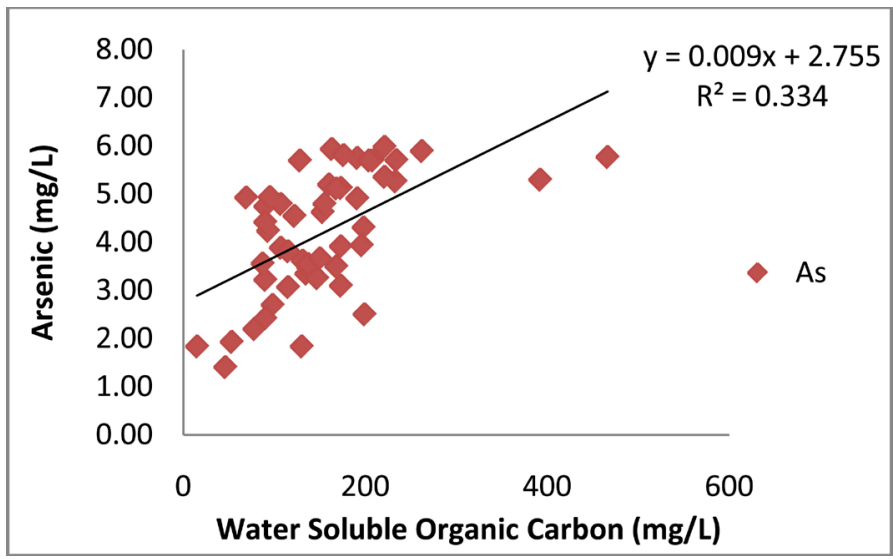

Figure 1. Relation between WSOC and As in five districts.

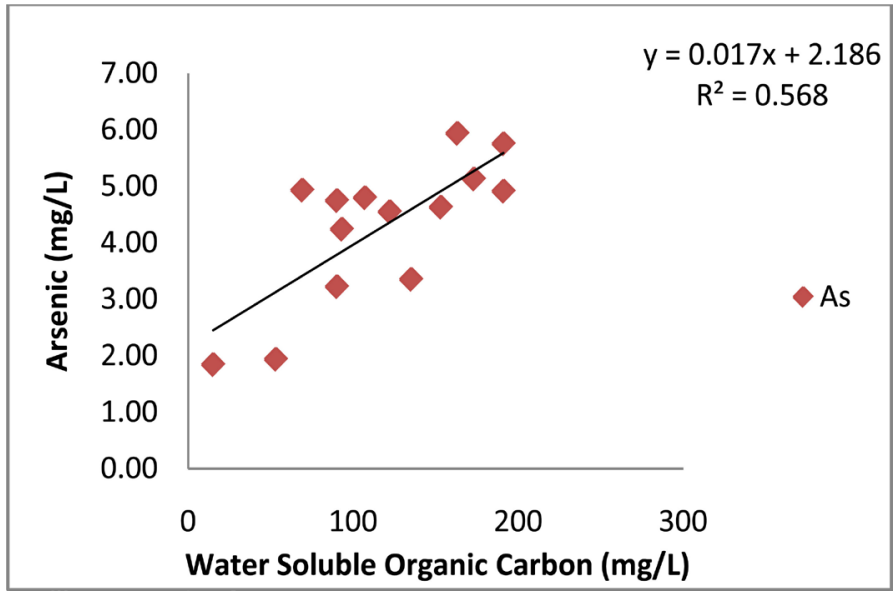

Figure 2. Relation between WSOC and As in Comilla district.

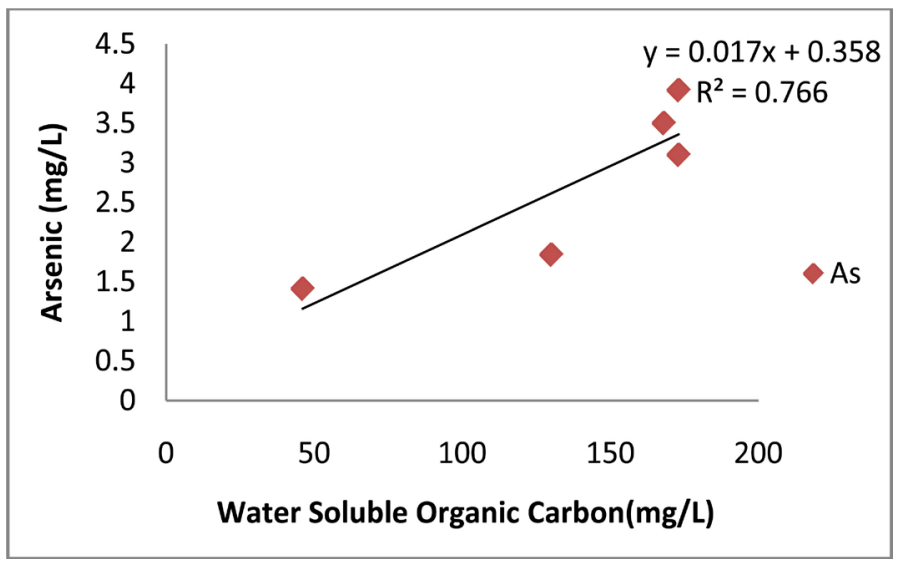

Figure 3. Relation between WSOC and As in Jessore district. 


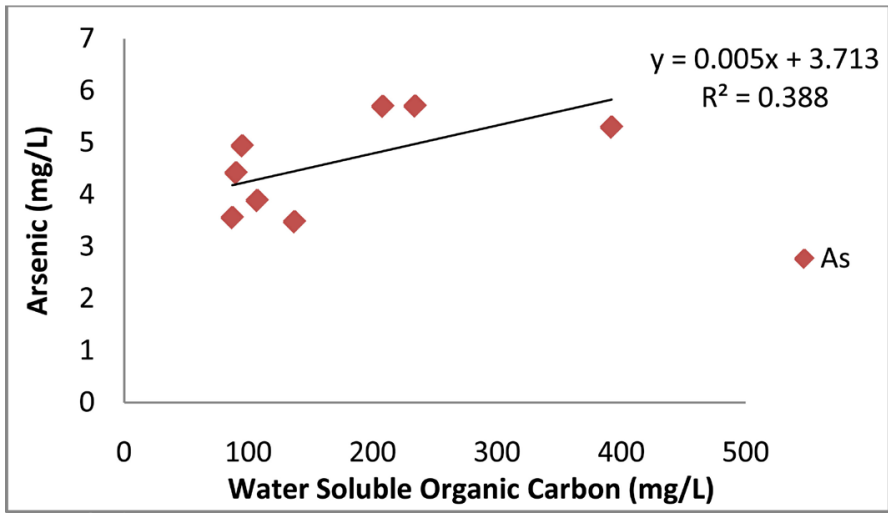

Figure 4. Relation between WSOC and As in Satkhira district.

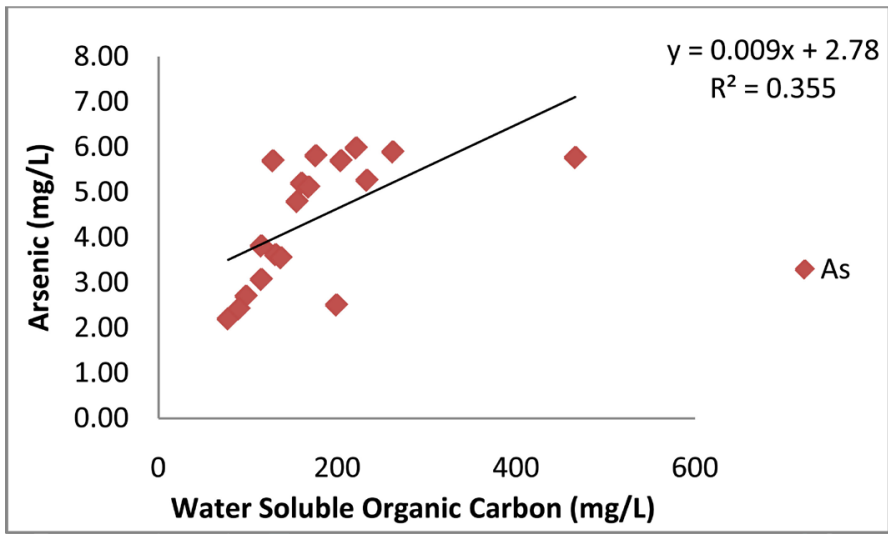

Figure 5. Relation between WSOC and As in Gopalganj district.

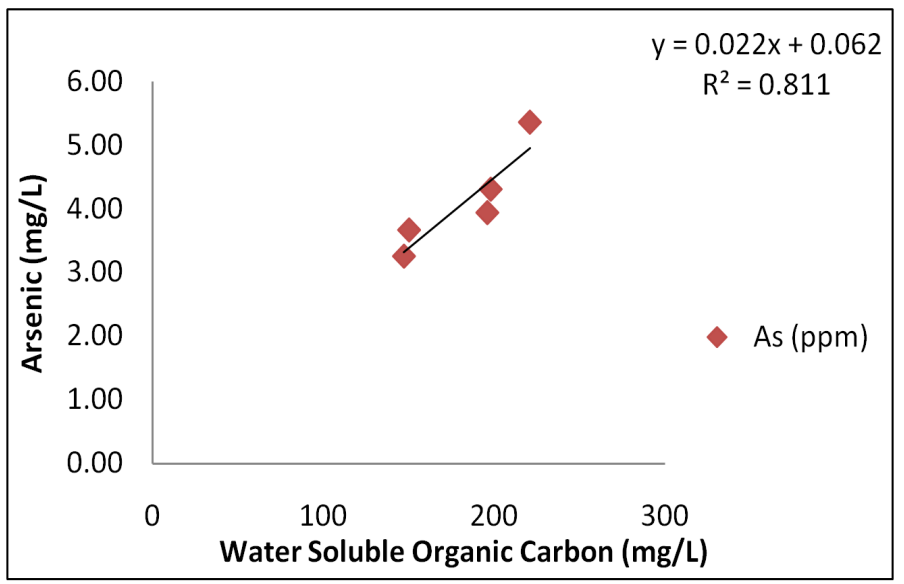

Figure 6. Relation between WSOC and As in Bagerhat district.

The distribution of organic matter, particularly peat deposits, in the aquifer sediments primarily controls the arsenic pollution mechanism. Peat beds are common beneath the old Meghna Estuarine Floodplain and Gopalganj-Khulna Peat Basins [12].

\section{Conclusion}

There are many debates on the theory of arsenic release in Bangladesh environ- 
ment. One important hypothesis is that organic deposits are responsible for its release in Bangladesh environment. It has been observed that there is a positive relationship between water soluble organic carbon and arsenic in the soils. The higher the water soluble organic carbon is, the higher the arsenic content. The present findings justify that organic or peat deposits could contribute in the release of arsenic in our environment.

\section{References}

[1] Meharg, A.A., Abedin, M., Rahman, M., Feldmann, J., Cotter-Howells, J. and Cresser, M.S. (2001) Arsenic Uptake and Metabolism in Bangladesh Rice Varieties. Arsenic in the Asia-Pacific Region Workshop, Adelaide, 20-23 November 2001, 4546.

[2] Ali, M.A., Badruzzaman, A.B.M., Jalil, M.A., Hossain, M.D., Ahmed, M.F., Masud, A.A., Kamruzzaman, M. and Rahman, M.A. (2003) Arsenic in Soil and Plant Environment of Bangladesh. In: Feroza, M.A., Ashraf, A.M. and Adeel, Z., Eds., Fate of Arsenic in the Environment, Bangladesh University of Engineering and Technology, Dhaka and United Nations University, Tokyo, 85-112.

[3] Imamul Huq, S.M. and Naidu, R. (2005) Arsenic in Groundwater and Contamination of Food Chain: Bangladesh Scenario. In: Bundschuh, Bhattacharya and Chandrashkharam, Eds., Natural Arsenic in Ground Water. Occurrence, Remediation and Management, Taylor and Francis Group, London, 95-102.

[4] Williams, P.N., Islam, M.R., Adomako, E.E., Raab, A., Hossain, S.A., Zhu, Y.G., Feldmann, J. and Meharg, A.A. (2006) Increase in Rice Grain Arsenic for Regions of Bangladesh Irrigating Paddies with Elevated Arsenic in Groundwaters. Environmental Science \& Technology, 40, 4903-4908. https://doi.org/10.1021/es060222i

[5] Sarifuzzaman, M., Siddique, M.N.A., Ferdousi, F.K., Ahmed, E., Shafiqul, A.M. and Ullah, S.M. (2007) Studies of Arsenic Mobilization with Iron, Manganese and Copper in Borehole Sediments of the River Padma. Pakistan Journal of Analytical \& Environmental Chemistry, 8, 91-95.

[6] World Health Organization (WHO) (2001) Arsenic in Drinking Water. http://www.who.int/inffs/en/fact210.html

[7] Tondel, M., Rahman, M., Magnuson, A., Chowdhury, I.A., Faruquee, M.H. and Ahmad, S.A. (1999) The Relationship of Arsenic Levels in Drinking Water and the Prevalence Rate of Skin Lesions in Bangladesh. Environmental Health Perspectives, 107, 727-729. https://doi.org/10.1289/ehp.99107727

[8] BGS (British Geological Survey) (2000) Groundwater Studies of Arsenic Contamination in Bangladesh. Executive Summary of the Main Report of Phase I, British Geological Survey and Mott Mac Donald (UK) for the Government of Bangladesh, Ministry of Local Government, Rural Development and Cooperatives, Department of Public Health Engineering, and Department for International Development (UK).

[9] Imamul Huq, S.M. (2008) Fate of Arsenic in Irrigation Water and Its Potential Impact on Food Chain. In: Ahuja, S., Ed., Arsenic Contamination of Groundwater. Mechanism, Analysis, and Remediation, John Wiley \& Sons, Inc., New York, 23-49.

[10] Alam, M.B. and Sattar, M.A. (2000) Assessment of Arsenic Contamination in Soils and Waters in Some Areas of Bangladesh. Water Science \& Technology, 42, 185193.

[11] Islam, F.S., Gault, A.G., Bootman, C., Polya, D.A. and Charnock, J.M. (2004) Role of Metal Reducing Bacteria in Arsenic from Bengal Delta Sediments. Nature, 430, 
68-71. https://doi.org/10.1038/nature02638

[12] Safiullah, S. (1998) Report on Monitoring and Mitigation of Arsenic in the Groundwater of Faridpur Municipality. CIDA Arsenic Project, 1-83.

[13] USDA (United States Department of Agriculture) (1951) Soil Survey Manual. Handbook No. 18, Soil Survey Staff, Bureau of Plant Industry, Soils and Agricultural Engineering, United States Department of Agriculture, Washington DC, 205.

[14] Vanchikova, E.V., Shamrikova, E.V., Sytar, T.S. and Kazakov, V.G. (2006) A New Method to Determine the Carbon Content of Water-Soluble Organic Compounds in Soils. Eurasian Soil Science, 39, 1084-1088. https://doi.org/10.1134/S1064229306100061

[15] Portman, J.E. and Riley, J.P. (1964) Determination of Arsenic in Seawater, Marine Plants and Silicate and Carbonate Sediments. Analytica Chimica Acta, 31, 509-519.

[16] Voth-Beach, L.M. and Shrader, D.E. (1985) Reduction of Interferences in the Determination of Arsenic and Selenium by Hydride Generation. Spectroscopy, 1, 6065.

\section{Scientific Research Publishing}

Submit or recommend next manuscript to SCIRP and we will provide best service for you:

Accepting pre-submission inquiries through Email, Facebook, LinkedIn, Twitter, etc. A wide selection of journals (inclusive of 9 subjects, more than 200 journals)

Providing 24-hour high-quality service

User-friendly online submission system

Fair and swift peer-review system

Efficient typesetting and proofreading procedure

Display of the result of downloads and visits, as well as the number of cited articles

Maximum dissemination of your research work

Submit your manuscript at: http://papersubmission.scirp.org/

Or contact ojss@scirp.org 